\title{
Replacement of soyabean meal by white lupin cv. Bardo seeds and the effectiveness of $\beta$-glucanase and xylanase in growing-finishing pig diets*
}

\author{
Marianna Flis $^{1}$, W. Sobotka ${ }^{1}$ and Z. Zduńczyk ${ }^{2}$ \\ 'Institute of Animal and Feed Management, \\ Olsztyn University of Agriculture and Technology \\ Oczapowskiego 5, 10-718 Olsztyn, Poland \\ ${ }^{2}$ Institute of Animal Reproduction and Food Research, \\ Division of Food Science, Polish Academy of Sciences \\ Tuwima 10, 10-718 Olsztyn, Poland
}

(Received 9 February 1998; accepted 24 Junc 1998)

\section{ABSTRACT}

The cffect of white $\mathrm{cv}$. Bardo lupin seeds on the fattening performance of 35 barrows weighing 24 to $96 \mathrm{~kg}$ was determined. In the first period of fattening (growing up to $65 \mathrm{~kg}$ ) the proportion of lupin seeds in the diets was 0,8 and $14 \%$, in the second period (finishing) 0,14 and $20 \%$. The amounts of lupin used replaced 0,30 and $50 \%$ of soyabean meal in the growing, and 0,75 and $100 \%$ in the finishing dicts. The effectiveness of an enzymatic preparation containing $\beta$-glucanase and xylanasc supplementing diets with varying proportions of soyabean and lupin and barley (52-65\%) was also studied. The digestibility of dietary nutrients, nitrogen balance, daily weight gain and feed utilization were estimiated.

The addition of white lupin seeds, containing $0.067 \%$ DM alkaloids, instead of soyabean meal did not have an unfavourable effect on nutrient digestibilities or nitrogen retention. Daily weight gains and feed utilization in pigs fed mixtures with an $8 \%$ (growing) and then $14 \%$ (finishing) lupin were the same as in the control group receiving soyabean meal. The higher proportion of lupin in the diets, i.e. $14 \%$ in the growing and $20 \%$ in the finishing diet, significantly decreased the growth rate of the pigs and leed utilization.

The addition of the $\beta$-glucanase and xylanase preparation $(0.1 \%$ Porzyme 9100$)$ increased only the digestibility of $\mathrm{N}$-frec extractives in the diets for young pigs (about $55 \mathrm{~kg}$ ) and in both periods of 
fattening increased daily nitrogen retention. The daily gains were higher $(3.6 \%)$ and the feed utilization was better $(4 \%)$ in pigs fed diets supplemented with enzyme preparation, but differences were not significant.

KEY WORDS: white lupin, barley, $\beta$-glucanase, xylanase, digestibility, growth, pigs

\section{INTRODUCTION}

White lupin seeds are an important source of protein in pig diets in many countries. It is assumed that the nutritive value of diets containing white lupin seeds is decreased by two groups of compounds: antinutrients, mainly quinolizidine alkaloids and nonstarch polysaccharides (NSP). Symptoms caused by elevated dietary alkaloids, also found when low-alkaloid varieties are fed, include vomiting, reduction of feed intake and growth rate of animals (Cheeke and Kclly, 1989; Hill and Pastuszewska 1993). Lupin NSP are digested only to a small degree in the small intestine of pigs (12-14\%) (Gdala et al., 1997), but undergo bacterial fermentation in the large intestine. Bacterial degradation of NSP is accompanied by loss of energy with gases and fermentation heat, and the energy of the short chain fatty acids formed in this process is less suitable for pigs than the energy from sugars absorbed in the small intestine (Just et al., 1983). It seems that an unfavourable effect of lupin NSP on the cnergy valuc of diets can be expected when diets with a high barley content are fed, since this grain also has considerable levels of NSP (18-20\% DM) (Bach Knudsen, 1997). About 50\% of the total NSP of barley comprises $\beta$-glucans and arabinoxylans (Henry, 1985). For this reason adding a preparation containing $\beta$-glucanase and xylanase to barley diets can be reasonable.

Because of their high sensitivity to lupin alkaloids, only varieties with very low levels of these compounds can be used in the feeding of pigs. From the studies of King (1981), Donovan et al. (1993) and Zettl et al. (1995) it results that the optimum level of low alkaloid white lupin seeds $(0.018-0.033 \%$ alkaloids $)$ for pigs over $25 \mathrm{BW}$ is $10-12 \%$. In earlier studies we found (Flis et al., 1997) that it is possible to obtain good results in feeding young pigs using a higher proportion of seeds of new varieties of white lupin $(20 \%)$ - these results were insignificantly worse than when soyabean meal was fed. Because of the small number of animals and short duration of that experiment, the results obtained in it required confirmation on a larger population over the whole fattening period and the use of seeds obtained from commercial plantations cultivating the new varieties. Seeds from commercial plantations may have higher alkaloid contents compared with small samples of seeds from experimental plant breeding stations.

The objective of this study was to determine the extent by which the newest white lupin variety, Bardo, can replace soyabean meal in the dicts of growing-finishing pigs. 
The effectiveness of an enzyme $\beta$-glucanase and xylanase preparation added to barley-wheat, soyabean and lupin diets for fattening pigs was also determined.

\section{MATERIAL AND METHODS}

\section{Animals and diets}

The experiment was carried out on 35 barrows (Polish Large White x Duroc), from about 24 to $96 \mathrm{~kg}$ body weight, housed individually and fed according to Nutrient Requirements of Pigs (1993). In two periods of fattening (up to 65 and over $65 \mathrm{~kg} \mathrm{BW}$ ) five isonitrogenous mixtures were used: a control soyabean diet (C), a feed with a lower lupin content (LL), a diet with a higher lupin content (HL), a control diet with the addition of enzymes $(\mathrm{C}+\mathrm{E})$ and the diet with the higher lupin content and enzyme preparation (HL+E). In the LL diet, 30 and $75 \%$ of soyabcan meal was replaced by lupin, in the HL diets, 50 and $100 \%$, respectively, in the growing and finishing diets. The enzyme preparation, Porzyme 9100, added in an amount of $0.1 \%$ of the diet, contained (according to the manufacturer, Finnfeeds International LTD), $400 \mathrm{U} / \mathrm{g} \beta$-glucanase and $400 \mathrm{U} / \mathrm{g}$ xylanase. The composition of diets are given in Table 1 . The feed was given twice daily moistened, and the animals had free access to water.

The experiment was conducted in two replicates. In the first $(A)$ the feeds were given to 3 barrows per group, in the second (B), to 4 . In both replicates, the protein feeds were from the same lot. Lupin seeds, containing $0.067 \% \mathrm{DM}$ alkaloids, from a commercial plantation that cooperates with plant breeding stations were used. The grains were from different lots but did not significantly differ in their chemical composition.

In replicate $B$, nutrient digestibilities were detcrmined twice (total collection method). The nitrogen balance was determined first when the growing diet was used (55 kg BW), and a second time during the finishing period ( $80 \mathrm{~kg} \mathrm{BW})$. Faeces and urine were collected through 5 days. Two average $10 \%$ samples were taken from the daily faeces output. One sample was conserved with sulphuric acid, the other was dried. Dry matter, crude ash, cther extract and crude fibre were determined in the pooled samples from each animal. Urine was collected in containers with the addition of sulphuric acid (urinary $\mathrm{pH}$ under 2). In pooled samples of dairy urine for each animal nitrogen was determined.

\section{Chemical analysis and calculation of nutritional value of the diets}

The basic dietary nutrients of diets, faeces and urinary nitrogen were determined using conventional methods. The amino acid content of the diets was esti- 
mated from their content in the diet components, the content of alkaloids was based on their content determined in lupin seeds. The NSP content in diets was calculated on the basis of literature data (Gdala and Buraczewska, 1996; Bach Knudsen, 1997). Calcium and total phosphorous contents in the diets were calculated from data in Nutrient Requirements of Pigs (1993). The metabolic energy content in the diets was estimated using the Hoffman and Schicmann cquation based on the chemical composition and digestibility coefficients determined experimentally, using the corrections for sugar and bacterially fermented structural polysaccharides (Nutrient Requirements of Pigs, 1993).

\section{Statistical analysis}

The experimental results were subjected to statistical analysis using the Duncan test, taking into account the bifactorial experimental design: groups and replicates.

\section{RESULTS AND DISCUSSION}

The average chemical composition and nutritive value of the diets, differed only slightly in replications $A$ and $B$, are given in Tables 1 and 2 .

The alkaloid content in the LL diets was 48 and $84 \mathrm{mg} / \mathrm{kg}$, and in the HL diets, 84 and $120 \mathrm{mg} / \mathrm{kg}$, in the first and second periods of fattening, respectively (Tables 1 and 2).

The digestibility coefficients of the nutrients and the results of the nitrogen balance are given in Table 3 . Replacing soyabean meal in the dicts for growing pigs with lupin seeds did not have a negative effect on the digestibility of the nutrients. Only a tendency towards decreasing the digestibility of crude protein as the amount of lupin in the diet increased was found (group LL and HL vs C). Also in the studies of Zettl et al. (1995) protein in diets containing 10 or $20 \%$ white lupin was less digestible than in the control soyabean diet. Crude protein, fibre and $\mathrm{N}$-free extractives digestibility were similar in the finishing C, LL and HL diets. The digestibility coefficients of the ether extract rose with increasing level of lupin seeds in the diet, hence of the content of the ether extract in it. The digestibility of the ether extract of the HL diet $(67.0 \%)$ was significantly higher than of the soyabean diet $\mathrm{C}(58.2 \%)$. The increase in apparent digestibility of ether extract of the diet as the content of white lupin increased was also observed in the experiment by Zetll et al. (1995). This was probably the result of two factors: the high digestibility of lupin fat (Roth-Meier and Kirchgessner, 1993; Flis et al., 1997) and the lower proportion of metabolic fat in the faeces of pigs fed diets with higher fat contents. 
TABLE 1

Composition and nutritional value of diets for growing pig (24-65 kg BW)

\begin{tabular}{|c|c|c|c|c|c|}
\hline \multirow[t]{2}{*}{ Indices } & \multicolumn{5}{|c|}{ Group } \\
\hline & $C^{\prime}$ & LL & $\mathrm{HL}$ & $\mathrm{C}-\mathrm{E}$ & $\mathrm{HL}+\mathrm{E}$ \\
\hline \multicolumn{6}{|l|}{ Ingredients, $\mathrm{g} / \mathrm{kg}$} \\
\hline barley & 562.0 & 544.4 & 524.3 & 561.0 & 529.3 \\
\hline wheal & 200.0 & 200.0 & 200.0 & 200.0 & 200.0 \\
\hline soyabcan meal (SBM) & 205.0 & 142.0 & 102.0 & 205.0 & 102.0 \\
\hline white lupin & $\cdots$ & 80.0 & 140.0 & - & 140.0 \\
\hline minerals ${ }^{2}$ & 23.0 & 23.0 & 23.0 & 23.0 & 23.0 \\
\hline mineral-vitamin premix & 7.0 & 7.0 & 7.0 & 7.0 & 7.0 \\
\hline L-lysine,HCL 78\% & 1.5 & 1.9 & 1.9 & 1.5 & 1.9 \\
\hline DL-methionine, $99 \%$ & 0.5 & 0.7 & 0.8 & 0.5 & 0.8 \\
\hline Fylax $^{3}$ & 1.0 & 1.0 & 1.0 & 1.0 & 1.0 \\
\hline Porzyme $9100^{4}$ & - & - & - & 1.0 & 1.0 \\
\hline \multicolumn{6}{|l|}{ Chemical analysis, $\%$ air dry basis } \\
\hline dry matter & 88.51 & 88.42 & 88.85 & 88.79 & 88.72 \\
\hline crude ash & 4.67 & 4.58 & 4.63 & 4.72 & 4.49 \\
\hline crude protein & 17.48 & 17.46 & 17.27 & 17.48 & 17.34 \\
\hline ether extract & 1.90 & 2.61 & 3.04 & 1.92 & 3.07 \\
\hline crude lïbre & 4.44 & 4.89 & 5.20 & 4.39 & 5.10 \\
\hline total alkaloids ${ }^{5}, \mathrm{mg} / \mathrm{kg}$ & & 48 & 84 & - & 84 \\
\hline $\mathrm{NSP}^{6}$ & 15.2 & 15.2 & 16.6 & 17.9 & 17.9 \\
\hline \multicolumn{6}{|l|}{ Nutritional value, $\mathrm{g} / \mathrm{kg}$} \\
\hline lysine $e^{5}$ & 9.2 & 9.2 , & 9.1 & 9.2 & 9.1 \\
\hline methionine 5 & 3.0 & 3.0 & 3.0 & 3.0 & 3.0 \\
\hline threonine ${ }^{5}$ & 6.1 & 6.0 & 6.0 & 6.1 & 6.0 \\
\hline tryptofan 5 & 2.1 & 1.9 & 1.8 & 2.1 & 1.8 \\
\hline $\mathrm{Ca}$ & 7.1 & 7.1 & 7.0 & 7.1 & 7.0 \\
\hline P-total & 5.6 & 5.6 & 5.5 & 5.6 & 5.5 \\
\hline metabolizable energy, $\mathrm{MJ} / \mathrm{kg}$ & 12.4 & 12.4 & 12.4 & 12.6 & 12.5 \\
\hline SBM subsitution by lupin, $\%$ & 0 & 30 & 50 & 0 & 50 \\
\hline
\end{tabular}

${ }^{1} \mathrm{C}=$ control, $\mathrm{LL}=$ low lupin diet, IIL $=$ high lupin diet, $\mathrm{C}+\mathrm{E}=$ control+enzymes, $\mathrm{HL}+\mathrm{E}=$ high lupin diet+enzymes

${ }^{2}$ limestone $(1.1 \%)+$ bicalcium phosphate $(0.9 \%)$ +salt $(0.3 \%)$

${ }^{3}$ preservation preparation

4 enzyme preparation ( $\beta$-glucanase $400 \mathrm{U} / \mathrm{g}$, xylanase $400 \mathrm{U} / \mathrm{g}$ )

5 value calculated according to analysed contents in feed ingredients

- value not determined but calculated according to literature data (Gdala and Buraczewska, 1996; Bach Knudsen, 1997) 
TABLE 2

Composition and nutritional value of diets for growing pig (65-95 kg BW)

\begin{tabular}{|c|c|c|c|c|c|}
\hline \multirow[t]{2}{*}{ Indices } & \multicolumn{5}{|c|}{ Group } \\
\hline & $\mathrm{C}^{1}$ & LL & HL & $\mathrm{C}+\mathrm{E}$ & $\mathrm{HL}+\mathrm{E}$ \\
\hline \multicolumn{6}{|l|}{ Ingredients, $\mathrm{g} / \mathrm{kg}$} \\
\hline barley & 648.1 & 602.5 & 572.5 & 647.1 & 571.5 \\
\hline wheat & 200.0 & 200.0 & 200.0 & 200.0 & 200.0 \\
\hline soyabean meal (SBM) & 125.0 & 30.0 & & 125.0 & - \\
\hline white lupin & - & 140.0 & 200.0 & - & 200.0 \\
\hline minerals ${ }^{2}$ & 17.0 & 17.0 & 17.0 & 17.0 & 17.0 \\
\hline mineral-vitamin premix & 7.0 & 7.0 & 7.0 & 7.0 & 7.0 \\
\hline L-lysine (HCL 78\%) & 1.6 & 1.9 & 1.8 & 1.6 & 1.8 \\
\hline DL-methionine $(99 \%)$ & 0.3 & 0.6 & 0.7 & 0.3 & 0.7 \\
\hline Fylax $x^{3}$ & 1.0 & 1.0 & 1.0 & 1.0 & 1.0 \\
\hline Porzyme $9100^{4}$ & - & - & - & 1.0 & 1.0 \\
\hline \multicolumn{6}{|l|}{ Chemical analysis, $\%$ air dry basis } \\
\hline dry matter & 88.24 & 88.47 & 85.52 & 88.33 & 88.69 \\
\hline crude ash & 3.85 & 3.69 & 3.55 & 3.91 & 3.66 \\
\hline crude protein & 14.84 & 15.07 & 15.33 & 14.94 & 15.40 \\
\hline ether extract & 1.94 & 3.17 & 3.62 & 1.92 & 3.54 \\
\hline crude fibre & 4.15 & 4.64 & 5.21 & 4.24 & 5.16 \\
\hline total alkaloids ${ }^{3}, \mathrm{mg} / \mathrm{kg}$ & - & 84 & 120 & - & 120 \\
\hline $\mathrm{NSP}^{6}$ & 15.0 & 17.7 & 18.9 & 15.0 & 18.9 \\
\hline \multicolumn{6}{|l|}{ Nutritional value, $\mathrm{g} / \mathrm{kg}$} \\
\hline lysine $e^{5}$ & 7.6 & 7.6 & 7.7 & 7.6 & 7.7 \\
\hline methionine ${ }^{5}$ & 2.5 & 2.5 & 2.5 & 2.5 & 2.5 \\
\hline threonine $\mathrm{e}^{s}$ & 5.2 & 5.2 & 5.2 & 5.2 & 5.2 \\
\hline tryptofan ${ }^{5}$ & 2.0 & 1.5 & 1.4 & 2.0 & 1.4 \\
\hline $\mathrm{Ca}$ & 5.5 & 5.4 & 5.4 & 5.5 & 5.4 \\
\hline P-total & 4.6 & 4.5 & 4.4 & 4.6 & 4.4 \\
\hline melabolizable energy, $\mathrm{MJ} / \mathrm{kg}$ & 12.5 & 12.5 & 12.7 & 12.6 & 12.6 \\
\hline SBM substitution by lupin, \% & 0 & 75 & 100 & 0 & 100 \\
\hline
\end{tabular}

${ }^{1} \mathrm{C}=$ control, $\mathrm{LL}=$ low lupin diet, $\mathrm{HL}=$ high lupin diet, $\mathrm{C}+\mathrm{E}-$ control+enzymes, $\mathrm{IIL}+\mathrm{E}=$ high lupin diet+enzymes

${ }^{2}$ limestone (1.0\% bicalcium phosphate $(0.4 \%)+$ salt $(0.3 \%)$

${ }^{3}$ preservation preparation

1 enzyme preparation (b-glucanase $400 \mathrm{U} / \mathrm{g}$, xylanase $400 \mathrm{U} / \mathrm{g}$ )

5 value calculated according to analysed contents in feed ingredients

${ }^{6}$ value not determined but calculated according to literature data (Gdala and Buraczewska, 1996; Bach Knudsen, 1997) 
TABLE 3

Digestibility coefficients and $\mathrm{N}$ balance (repetition $\mathrm{B}$ )

\begin{tabular}{|c|c|c|c|c|c|c|}
\hline & \multicolumn{5}{|c|}{ Group } & \multirow{3}{*}{ SE } \\
\hline & $\mathrm{C}^{\prime}$ & LL & HL & $\mathrm{C}+\mathrm{E}$ & $\mathrm{HL}+\mathrm{E}$ & \\
\hline & $0-0^{2}$ & $8-14$ & $14-20$ & $0-0$ & $14-20$ & \\
\hline & \multicolumn{5}{|c|}{ Growing period (55 kg BW) } & \\
\hline Digestibility coefficient, $\%$ & $\mathrm{n}=4$ & $\mathrm{n}=4$ & $\mathrm{n}=4$ & $\mathrm{n}=4$ & $\mathrm{n}=4$ & \\
\hline crude protein & 82.0 & 81.0 & 80.4 & 84.1 & 80.6 & 0.28 \\
\hline ether extract & 56.1 & 56.1 & 57.2 & 61.2 & 60.7 & 0.80 \\
\hline crude fibre & 40.3 & 43.9 & 42.3 & 45.4 & 43.8 & 1.11 \\
\hline $\mathrm{N}$-free extractives & 90.6 & 91.5 & 90.8 & 91.4 & 91.3 & 0.09 \\
\hline \multicolumn{7}{|l|}{$\mathrm{N}$ balance } \\
\hline intake, g/day & 55.0 & 55.0 & 54.8 & 55.3 & 54.4 & 0.13 \\
\hline retained, g/day & 19.0 & 21.5 & 18.1 & 20.8 & 20.2 & 0.41 \\
\hline $\mathrm{N}$ retained: $\mathrm{N}$ intake, $\%$ & 34.4 & 39.0 & 33.1 & 37.6 & 37.2 & 0.72 \\
\hline & \multicolumn{6}{|c|}{ Finishing period ( $80 \mathrm{~kg} \mathrm{BW}$ ) } \\
\hline Digestibility coefficient, $\%$ & & & & & & \\
\hline crude protein & 80.7 & 80.3 & 80.4 & 82.7 & 80.9 & 0.21 \\
\hline ether extract & $58.2^{\mathrm{B}}$ & $62.5^{\mathrm{AB}}$ & $67.0^{\mathrm{A}}$ & $63.8^{\mathrm{AB}}$ & $63.7^{\mathrm{AB}}$ & 0.45 \\
\hline crude fibre & 37.4 & 38.3 & 43.7 & 38.6 & 43.2 & 0.66 \\
\hline $\mathrm{N}$-free extractives & 91.2 & 91.6 & 92.5 & 91.5 & 91.7 & 0.12 \\
\hline \multicolumn{7}{|l|}{$\mathrm{N}$ balance } \\
\hline intake, g/day & 60.0 & 59.8 & 61.8 & 60.4 & 60.9 & 0.09 \\
\hline retained, g/day & 19.8 & 20.4 & 18.5 & 20.3 & 20.0 & 0.50 \\
\hline $\mathrm{N}$ retained: $\mathrm{N}$ intake, $\%$ & 33.1 & 34.1 & 29.9 & 33.5 & 32.9 & 0.82 \\
\hline
\end{tabular}

${ }^{1}$ see under Table 1 and 2;

${ }^{2}$ share of the lupin seeds in growing-finishing pig diet; SE- standard error of the mean means within a row with different superscripts are significantly different: $a, b-P<0.05$, A, $\mathrm{B}-\mathrm{P}<0.01$

Supplementing of $\beta$-glucanase and xylanase preparations to the control diet and lupin diets had only a slight effect during the growing period (Table 3 ). The digestibility of crude protein, ether extract and crude fibre decreased insignificantly, while that of $\mathrm{N}$-free extractives declined significantly $(\mathrm{P}<0.05)$. During the finishing period no effects of enzyme additives on the digestibility of dietary components was found.

Literature data point to the differentiated effect of enzyme supplementation on the digestibility of nutrients of pig diets. In animals over $30 \mathrm{~kg}$ fed barley diets Thacker et al. (1992 a,b) and Baas and Thacker (1996) found that enzyme preparations in which $\beta$-glucanase predominated did not have a significant effect 
on the apparent digestibility of nutrients. Baas and Thacker (1996), however, found a tendency for higher digestibility of dry matter, crude protein (from 74.1 to 77.2 and $78.6 \%$ ) and energy when Porzyme preparation containing $\beta$-glucanase (which retains a considerable part of its initial activity in the duodenum 60 and $240 \mathrm{~min}$ after feeding) was added. A significant rise in the intestinal digestibility of $\beta$-glucans and arabinoxylans and the apparent digestibility of barley crude protein and arabinoxylans after adding $\beta$-glucanase to the diets of older pigs (40 and $80 \mathrm{~kg}$ ) was found by Graham et al. (1988).

Daily nitrogen retention during growing period equaled $21.5 \mathrm{~g}$ in the $\mathrm{LL}$ group, $18.1 \mathrm{~g}$ in the $\mathrm{HL}$ group and did not significantly differ from that in group C (19.0 g) (Table 3). In the finishing period too, daily nitrogen retention in pigs fed diets containing lupin did not differ significantly from nitrogen retention in pigs fed the control diet. The utilization of absorbed nitrogen equaled $34.4,39.0$ and $33.1 \%$ in the growing period $(55 \mathrm{~kg}$ ) and $33.1,34.1$ and $29.9 \%$ in the finishing period $(80 \mathrm{~kg})$, respectively in groups $\mathrm{C}$, LL and IIL, and did not differ significantly. A tendency towards decreasing daily nitrogen retention and utilization of absorbed nitrogen was seen in pigs receiving the diets with higher lupin contents (group HL vs C).

The addition of $\beta$-glucanase and xylanase to the barley-wheat diets caused an insignificant increase in daily nitrogen retention, by $2 \mathrm{~g}$ during the growing and 1 $\mathrm{g}$ during the finishing periods. During the finishing period the effect of adding enzymes on the retention and utilization of absorbed nitrogen was somewhat higher in the group fed the lupin containing diet (HL+E vs HL) than in the control diet $(\mathrm{C}+\mathrm{E}$ vs $\mathrm{C})$. The slightly higher, but statistically insignificant, daily retention of nitrogen in pigs receiving feed with $\beta$-glucanase and xylanase preparation may indicate point a higher crude protein digestibility of the diets in the small intestine.

The daily weight gains of pigs fed the LL diets (with the low lupin content) equaled $687 \mathrm{~g}$ and were the same as in the control group $\mathrm{C}$ (soyabcan), $684 \mathrm{~g}$. Feed intake per kilogram weight gain in group LL $(3.07 \mathrm{~kg})$ was similar to that in group C (3.11 kg) (Table 4).

The daily weight gains of pigs fed the diets with the higher lupin content (HL) were insignificantly lower during the growing period $(594 \mathrm{~g})$ than of the control group $\mathrm{C}$. In the finishing period, when the proportion of lupin in the diet increased to $20 \%$, daily weight gains in the HL group were significantly $(\mathrm{P}<0.05)$ lower than in group C. Also, during the whole fattening period, the daily weight gains of pigs fed the HL diet were significantly lower than in group C. In comparison with the controls, during the whole fattening period, the HL pigs consumed significantly more feed ( 3.31 vs $3.11 \mathrm{~kg}$ ), metabolic energy (41.5 vs $38.6 \mathrm{MDI}$ ) and crude protein (541 vs $505 \mathrm{~g}$ ) per $\mathrm{kg}$ weight gain.

The lower daily weight gain and worse feed utilization in pigs fed the diet with the higher lupin content (HL) can be attributed in part to the unfavourable effect of 
TABLE 4

Average daily gain and fecd conversion efficiency (repetition $\mathrm{A}+\mathrm{B}$ )

\begin{tabular}{|c|c|c|c|c|c|c|}
\hline & \multicolumn{5}{|c|}{ Group } & \multirow[b]{2}{*}{ SE } \\
\hline & $\begin{array}{c}\mathrm{C}^{1} \\
0-0^{2}\end{array}$ & $\begin{array}{c}\text { LL } \\
8-14\end{array}$ & $\begin{array}{c}\text { HL } \\
14-20\end{array}$ & $\begin{array}{c}C+E \\
0-0\end{array}$ & $\begin{array}{c}\mathrm{HL}+\mathrm{E} \\
14-20\end{array}$ & \\
\hline Number of pigs & 7 & 7 & 7 & 7 & 7 & \\
\hline Initial $\mathrm{BW}^{3}, \mathrm{~kg}$ & 24.3 & 24.3 & 24.1 & 24.0 & 24.6 & 0.29 \\
\hline Final BW, kg & 97.6 & 97.9 & 92.4 & 98.3 & 95.9 & 0.48 \\
\hline \multicolumn{7}{|l|}{$\mathrm{ADG}^{4}, \mathrm{~g}$ day } \\
\hline $24-65$ & $632^{\text {abc }}$ & $645^{\mathrm{ab}}$ & $594^{\mathrm{cb}}$ & $656^{\mathrm{aA}}$ & $609^{\mathrm{bc}}$ & 10.01 \\
\hline $65-95$ & $771^{\lrcorner}$ & $757^{\mathrm{ab}}$ & $710^{\mathrm{bB}}$ & $789^{\mathrm{a} \Lambda}$ & $760^{\mathrm{ab}}$ & 6.51 \\
\hline $24-95 \mathrm{~kg}$ & $684^{\mathrm{ab}}$ & $687^{\mathrm{ab}}$ & $637^{\mathrm{cB}}$ & $705^{\mathrm{aA}}$ & $665^{b c}$ & 7.71 \\
\hline Relative, $\%$ & 100 & 100.4 & 93.1 & 103.1 & 97.2 & \\
\hline \multicolumn{7}{|l|}{$\mathrm{FCE}^{5}, \mathrm{~kg} / \mathrm{kg}$} \\
\hline $24-65$ & $2.80^{\mathrm{al}}$ & $2.71^{\mathrm{b}}$ & $2.95^{\mathrm{a}}$ & $2.71^{\mathrm{b}}$ & $2.86^{\mathrm{ab}}$ & 0.02 \\
\hline $65-95$ & $3.54^{\mathrm{b}}$ & $3.62^{\mathrm{ab}}$ & $3.83^{\mathrm{aA}}$ & $3.45^{\mathrm{bB}}$ & $3.56^{\mathrm{b}}$ & 0.02 \\
\hline $24-95 \mathrm{~kg}$ & $3.11^{b}$ & $3.07^{h}$ & $3.31^{\mathrm{BA}}$ & $3.01^{\mathrm{bB}}$ & $3.16^{\mathrm{ab}}$ & 0.02 \\
\hline Relative, $\%$ & 100 & 98.7 & 106.4 & 96.8 & 101.6 & \\
\hline \multicolumn{7}{|c|}{ ME:BWgain, $\mathrm{MJ} / \mathrm{kg}$} \\
\hline $24-65$ & $34.7^{\mathrm{ab}}$ & $33.5^{\mathrm{b}}$ & $36.5^{3}$ & $34.2^{\mathrm{ab}}$ & $35.6^{\mathrm{ab}}$ & 0.37 \\
\hline $65-95$ & $44.2^{b}$ & $45.3^{b}$ & $48.5^{\mathrm{aA}}$ & $43.5^{\mathrm{bB}}$ & $44.8^{\mathrm{b}}$ & 0.36 \\
\hline $24-95 \mathrm{~kg}$ & $38.6^{\mathrm{H}}$ & $38.3^{\mathrm{B}}$ & $41.5^{\mathrm{A}}$ & $38.0^{\mathrm{B}}$ & $39.5^{\mathrm{B}}$ & 0.33 \\
\hline \multicolumn{7}{|c|}{$\mathrm{CP}^{\dagger}: \mathrm{BW}$ gain, g/kg } \\
\hline $24-65$ & 490 & 473 & 511 & 475 & 496 & 5.76 \\
\hline $65-95$ & $525^{\mathrm{hB}}$ & $545^{\mathrm{h}}$ & $586^{\mathrm{aA}}$ & $515^{\mathrm{bB}}$ & $548^{\mathrm{B}}$ & 5.21 \\
\hline $24-95 \mathrm{~kg}$ & $505^{b}$ & $501^{\mathrm{bB}}$ & $541^{\mathrm{aA}}$ & $491^{\mathrm{bB}}$ & $518^{a b}$ & 5.19 \\
\hline
\end{tabular}

I sce under Table l;

2 share of the lupin seeds in growing-finishing pig diets; SE - standard error of the mean

${ }^{3}$ body weight

${ }^{4}$ average daily gain

${ }^{5}$ feed conversion efficiency

${ }^{6}$ crude protcin

means within a row with different superseripts are significantly different: $a, b, c-P<0.05$, A, B $-\mathrm{P}<0.0$

alkaloids. Although the alkaloid content in the HL diet was not high (84 and 120 $\mathrm{mg} / \mathrm{kg}$, during growing and finishing period, respectively), similarly as the HL+E diet, it was unwillinghly consumed. In the study by Buraczewska et al. (1993) it was found that the level of white lupin alkaloids tolerated by young pigs (20-45 $\mathrm{kg}$ ) was about $120 \mathrm{mg} / \mathrm{kg}$. In our experiment, the HL diet contained this level of alkaloids during the finishing period $(65-95 \mathrm{~kg})$. However, in the studies of King (1981), a decline in the growth rate of pigs was seen even at a relatively low dietary alkaloid content $(20.7 \%$ white lupin containing $0.018 \%$ alkaloids). It is also possible that the slightly higher content of nonstarch polysaccharides from 
the lupin in the HL diet than in the C dict (18.9 and $15.0 \%$, respectively in the finishing diets) lowered the energy value of this diet, and in this way, in addition to alkaloids, also negatively affected animals performance.

The addition of the enzyme preparation both to the control diet $(\mathrm{C}+\mathrm{E})$ and to the diet with the higher lupin content $(\mathrm{HL}+\mathrm{E})$ did not significantly affect daily weight gain and feed utilization (Table 4). In considering the joint effects of the addition of enzymes, the tendency to increase gains (by 3.6\%) and to decrease feed consumption (by $4.0 \%$ ) per $\mathrm{kg}$ weight gain was found. The effect of $\beta$-glucanase and xylanase on weight gain and feed utilization in pigs weighing $24-95 \mathrm{~kg}$ was not significant, but was higher than in the study of Thacker et al. (1992 a,b) and Baas and Thacker (1996).

\section{CONCLUSIONS}

The results obtained in this study show that in pig feeding practice, when using feeds with a predominance of barley, white lupin cv. Bardo $(0.067 \% \mathrm{DM}$ alkaloids) can be used in amounts of $8 \%$ of the diet in the growing and $14 \%$ in the finishing periods. The addition of an enzyme preparation containing $\beta$-glucanase and xylanase $(0.1 \%$ Por $z y m e 9100)$ to a barley-wheat diet containing soyabean meal or to a diet with a high level of white lupin insignificantly increased daily weight gain (by $3.6 \%$ ) and feed utilization (by $4.0 \%$ ).

\section{REFERENCES}

Bach Knudsen K. E., 1997. Carbohydrate and lignin contents of plant materials used in animal feeding. Anim. Fecd Sci. Technol. 67, 319-338

Baas T. C., Thacker P. A., 1996. Impact of gastric pH on dietary enzyme activity and survivability in swine fed $\beta$-glucanase supplemented diets. Can. J. Anim. Sci. 76, 245-252

Buraczewska L., Pastuszewska B., Smulikowska S., Wasilewko J., 1993. Response of pigs, rats and chickens to dietary level of alkaloids lupin species. In : A.F. B van der Poel, J. Huisman, H.S. Saini (Editors). Proceedings of the 2nd International Workshopon Antinutritional Factors (ANFs) in Lcgume secds. Wagenningen Pers. Wagenningen, pp. 371-376

Cheeke P.R., Kelly J.D.,1989. Metabolism, toxicity and nutritional implications of quinolizidine (lupin) alkaloids. In: J. Iluisman, A.F.B. van der Poel and I. E. Liener (Editors). Recent advances of research in antinutritional factors in legume seeds. PUDOC, Wagcnningen, pp. 189-201

Donovan B.C., McNiven M.A., van Lunen T. A., Anderson D.M., McLead J.A., 1993. Replacement of soyabean meal with dehydrated lupin seeds in pigs diets. Anim. Feed Sci. Technol. 43,77-85

Flis M., Sobotka W., Zdunczyk Z., 1997. Effect of variety and dehulling on nutritional value of white lupin seeds for growing pigs. J. Anim. Feed Sci. 6, 521-531 
Gdala J., Buraczewska L., 1996. Chemical composition and carbohydrate content of seeds from several lupin species. J. Anim. Feed Sci. 5, 403-416

Gdala J., Jansman A. J. M., Buraczewska L., Huisman J., van Leeuwen l'., 1997. The influence of $\propto$-galactosidase supplementation on ileal digestibility of lupin seed carbohydrates and dietary protein in young pigs. Anim. Feed Sci. Technol. 67, 115-125

Graham H., Åman P., Lowgren W., 1988. Enzyme supplementation of pig feeds. In: Proceedings of 4th International Seminar on Digestive Physiology in the Pig. L. Buraczewska, S. Buraczewski, B. Pastuszewska, T. Żebrowska (Editors). The Kielanowski Institute of Animal Physiology and Nutrition, Jabłonna (Poland), pp. 371-376

Henry R.J., 1985. A comparision of the non-starch carbohydrates in cercal grains. J. Sci. Food Agric. 36, 1243-1253

Hill G.D., Pastuszewska B., 1993. Lupin alkaloids and their role in animal nutrition.In: A.F.B. van der Poel, J. Huisman and H.S.Saini (Editors). Recent advances of research in antinutritional factors in legume seeds. Wageningen Pers, Wageningen, pp. 343-362

Just A., Fernandez J. A., Jorgensen H., 1983. The net encrgy value of dicts for growth in pigs in relation to the fermentative processes in the digestive tract and the site of absorption of the nutrients. Livest. Prod. Sci. 10, 171-186

King R. H., 1981. Lupin-seed meal (Lupinus albus cv. Hamburg) as a source of protein for growing pigs. Anim. Feed Sci. Technol. 6, 285-296

Nutrient Requirements ol Pigs. Nutritive Value of Feeds (in Polish) 1993. The Kielanowski Institute of Animal Physiology and Nutrition (Editor). Jabłonna (Poland)

Roth-Maier D. A., Kirchgessner M., 1993. Nährstoffzusammensetung und I utterwerte verschiedener weisser und gelber Lupinen (Lupinus albus L. und Lapinus luteus I..) für Schwein und Gellügcl. Agribiol. Res. 46, 218-228

Thacker P. A., Campbell G. L., GrootWassink J.W. D., 1992a. Effect of salinomycin and enzyme supplementation on nutrient digestibility and the performance of pigs fed barley-or rye-based diets. Can. J. Anim. Sci. 72, 117-125

Thacker P. A., Campbell G. I.., GrootWassink J.W. D., 1992b. The effect of organic acids and enzyme supplementation on the performance of pigs fed barlcy-based dicts. Can. J. Anim. Sci. 72, 395-402

Zettl von A., Lettner F., Wetscherek W., 1995. Einsatz von weisser Süsslupine (Lupinus albus var. Amiga) in der Schweinemast. Bodenkultur, 46, 165-167

\section{STRESZCZENIE}

\section{Zastąpienie poekstrakcyjnej śruty sojowej lubinem bialym odmiany Bardo oraz efektywność preparatu $\beta$-glukanazy i ksylanazy w żywieniu tuczników}

Badano wpływ udziału nasion łubinu białego odmiany Bardo na efekty tuču 35 wieprzków od ok. 24 do $96 \mathrm{~kg}$ masy ciała. W pierwszym okresie tuc $\%$ (grower - do $65 \mathrm{~kg}$ ) udział nasion łubinu w mieszankach wynosił 0,8 i $14 \%$, a w drugim (finisher) 0,14 i $20 \%$, zastępując nimi 0,30 i $50 \%$ poekstrakcyjnej śruty sojowcj w okresic grower oraz 0,75 i $100 \%$ w okresie finisher. Określono również efektywność dodatku preparatu enzymatycznego z $\beta$-glukanazą i ksylanazą do diet 7 różnym udziałem poekstrakcyjnej śruty sojowej i łubinu oraz dużym udziałem jęczmienia (52-65\%). 
Oznaczono strawność składników pokarmowych diet, bilans azotu oraz dzienne preyrosty i wykorzystanic paszy.

Zastapienie śrutą łubimu białego $(0.067 \%$ s.m. alkaloidów) pockstrakcyjncj śruty sojowcj nic wpłynęło ujemnie na strawność składników pokarmowych diet i retencję azotu. Dzienne przyrosty i wykorzystanie paszy u świń żywionych mieszankami z udzialem $8 \%$ (grower), a następnie 14\% (finisher) łubinu były takie same jak w grupic kontrolnej. Wiçkszy udział lubinu w mieszankach, $\mathbf{t j}$. $14 \% \mathrm{w}$ grower i $20 \% \mathrm{w}$ finisher istotnie zmniejszył tempo wzrostu świń i spowodował pogorszenic wykor $\angle y s t a n i a$ pas $\angle y$.

Dodatek preparatu z $\beta$-glukanazą i ksylanazą (0.1\% Por zyme 9100), oprócz ^większenia strawności związków bezazotowych wyciagowych, nie wpłynąl na strawność składników pokarmowych diet młodych świń (ok. $55 \mathrm{~kg}$ ). W obu okrcsach tuczu spowodował natomiast zwiększenie (P>0.05) dziennej retencji azotu. Świnie otrzymujące dodatek enzymów miały wiçksze (o $3.6 \%$ ) dzienne przyrosty i lepiej (o $4.0 \%$ ) wykorzystywały paszę, lecz różnice te nie były istotne. 